\title{
Panniculitis in a patient with dermatomyositis
}

\author{
Paniculitis en paciente con dermatomiositis
}

\author{
Mariana Arias ${ }^{1}$ \\ Lais Gomes Barbosa Cunha ${ }^{2}$ \\ Alejandra Abeldaño ${ }^{4}$
}

\author{
María Inés Hernández ${ }^{1}$ \\ María Cristina Kien ${ }^{3}$
}

\begin{abstract}
Panniculitis is a rarely reported clinical finding in dermatomyositis. It may precede the other manifestations associated with dermatomyositis by as much as 14 months. In all cases, myositis and panniculitis improve simultaneously during treatment. The present report describes the case of a 30-year-old female patient with clinical and histopathological findings consistent with panniculitis two months after the onset of the muscle and cutaneous symptoms that permitted diagnosis of dermatomyositis. The skin lesions regressed following steroid treatment.

Keywords: Dermatomyositis; Panniculitis; Steroids

Resumen: La paniculitis es una manifestación cutánea infrecuente de la dermatomiositis. Puede preceder hasta en 14 meses a otras manifestaciones de la dermatomiositis. En todos los casos, la miositis y la paniculitis presentan mejoría simultánea durante el tratamiento. Describimos una paciente de sexo femenino de 30 años que presenta lesiones clínica e histológicamente compatibles con paniculitis luego de 2 meses de que el compromiso muscular y cutáneo permitió el diagnóstico de dermatomiositis. Las lesiones cutáneas remitieron con el tratamiento esteroideo.

Palabras-clave: Dermatomiositis; Esteroides; Paniculitis
\end{abstract}

\section{INTRODUCTION}

Panniculitis is a rare skin manifestation of dermatomyositis. Clinically, it presents as painful nodules or plaques on the arms, thighs and buttocks that resemble lobular panniculitis at histopathology. The skin lesions generally occur simultaneously with muscle symptoms.

The present report describes a 30-year old female patient presenting with lesions that were clinically and histologically compatible with panniculitis, followed two months later by muscle and cutaneous symptoms, later diagnosed as dermatomyositis. Regression of the skin lesions was achieved with steroid treatment.

\section{Case Report}

A 30-year old female patient with no relevant medical history was admitted to the Clinical Medicine Department for asthenia, debility and myalgias of approximately 45 days duration. She also reported polyarthralgia and swallowing disorders.

At physical examination, she was found to have edematous, purplish eyelids and patches of alopecia with desquamation on her scalp. No other skin lesions were found. After 15 days, erythematous, hot, painful plaques and nodules appeared around her upper and lower limbs (Figures 1 and 2). Biopsy (Protocol \#213124) revealed lobular panniculitis with mucin deposits associated with collagenopathy (Figures 3 and 4). The following supplementary tests were performed:

- Laboratory tests. The findings are summarized in Table 1.

- Electromyogram, the results of which discarded the possibility of any neurogenic involvement. Some mild proximal myogenic responses.

\footnotetext{
Received on 10.06 .2009

Approved by the Advisory Board and accepted for publication on 01.07.09.

* The study was conducted at the Hospital General de Agudos Dr. Cosme Argerich, Buenos Aires, Argentina.

Conflict of interest: None / Apoyo financiero: Ninguno

Financial funding: None / Conflicto de intereses: Ninguno

Physician, Hospital General de Agudos Dr. Cosme Argerich, Buenos Aires, Argentina.

Dermatologist. Hospital General de Agudos Dr. Cosme Argerich, Buenos Aires, Argentina.

Head of the Department of Dermatopathology, Hospital General de Agudos Dr. Cosme Argerich, Buenos Aires, Argentina.

Department Head, Hospital General de Agudos Dr. Cosme Argerich, Buenos Aires, Argentina. 


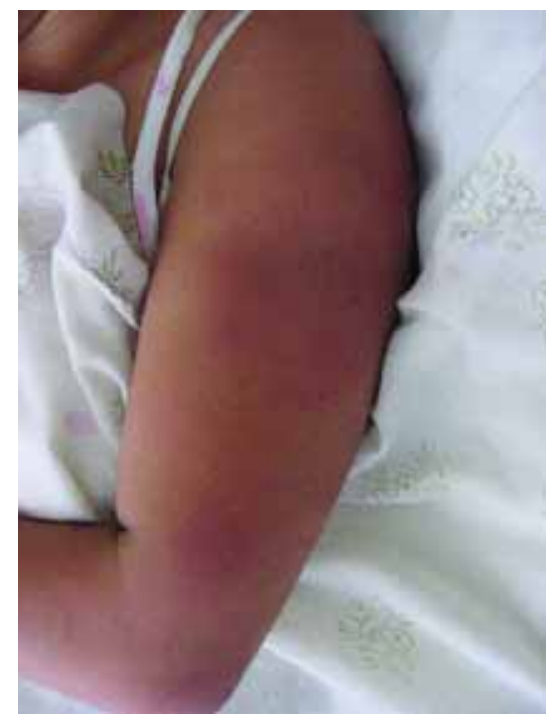

Figure 1: Hot, painful, erythematous nodules around the upper limbs
- Biopsy of the deltoid muscle (Protocol \#212999): Multifocal, perimysial and perivascular lymphoplasmacytic inflammatory infiltrate. Necrosis of isolated myofibers.

- Two-dimensional echocardiogram, abdominal echography, high-resolution computed axial tomography (HR-CAT) of chest and brain: All normal.

- Spirometry: mild restrictive ventilatory defect.

- Gynecological evaluation: Normal

- Otolaryngological evaluation by videofluoroscopic swallowing examination: mild oropharyngeal dysphagia without intraoral pressure.

Diagnosis: Panniculitis - Dermatomyositis

Treatment was initiated with meprednisone $60 \mathrm{mg} /$ day and a good clinical response was obtained. The panniculitis lesions regressed and there was an improvement in muscle symptoms and laboratory tests one week after initiation of steroid treatment.

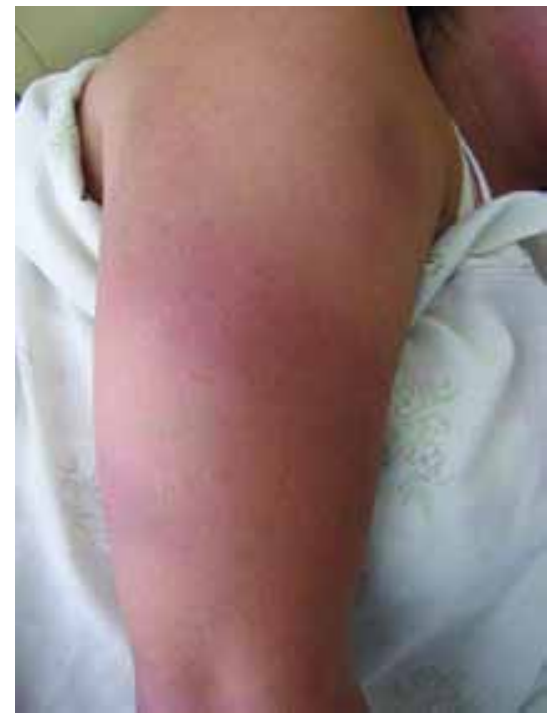

Figure 2: Hot, painful, erythematous nodules around the upper limbs

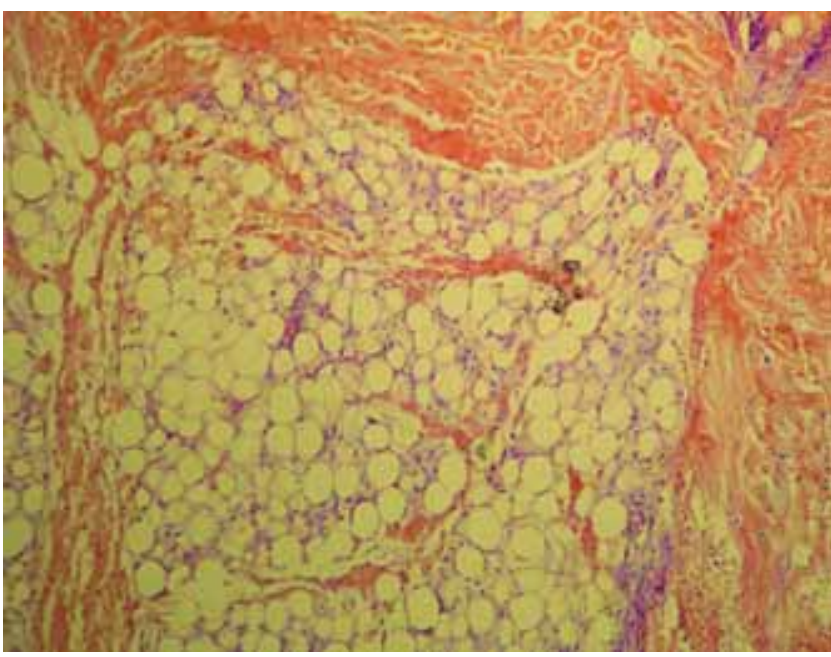

FIgURE 3: Lobular panniculitis with mucin deposits

\section{Discussion}

The several skin manifestations of dermatomyositis are well known, ${ }^{1,2}$ although panniculitis has rarely been described since the first paper published by Weber and Gray in 1924. ${ }^{3}$ Panniculitis is the collagen disease that is most commonly found during the course of systemic lupus erythematosus. ${ }^{3}$

Clinically, subcutaneous involvement presents as erythematous, indurated, painful plaques or nodules situated on the arms, thighs and buttocks, as shown in the present case. Less commonly, the condition may present with asymmetrical, multifocal lipoatrophy without induration. ${ }^{3-5}$

In all cases, myositis and panniculitis follow a parallel clinical course, with both conditions improving simultaneously during treatment. ${ }^{6}$ Recurrence of both conditions has been reported if the steroid treatment is discontinued abruptly. ${ }^{4,7}$ Panniculitis may precede the other symptoms of dermatomyositis by

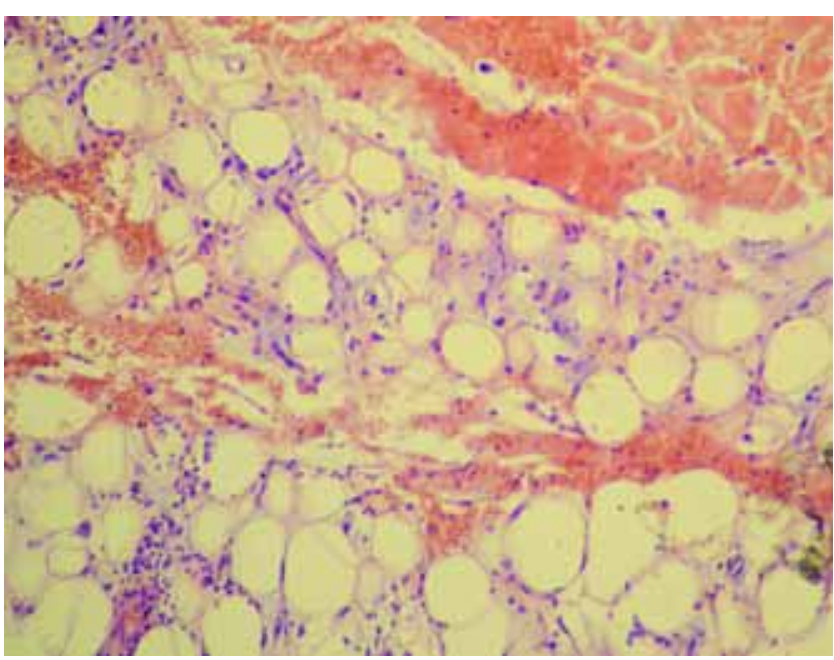

Figure 4: The same features in greater detail 
CharT 1: Laboratory tests

Tricytopenia (hematocrit 35\%, white blood cells 2,400 cells $/ \mathrm{mm} 3$, platelets 89,000 cells $/ \mathrm{mm} 3$ )

Muscle enzymes: CPK 211 IU/1 (Normal Range [NR]: 24-195), LDH 1,199 IU/1 (NR: 230-460), aldolase 9.8 IU/1 (NR: 0-7.6) Liver function: SGOT 365 IU/1 (NR: 0-38), SGPT 226 IU/1 (NR: 0-41), ALP 426 IU/1 (NR: 50-250) and GGT 108 IU/ (NR: 7-50) Serum complement: C3 reduced, C4 normal Immunological profile (ANF, anti-DNA, anti-Sm, anti-Jo1, anti-La, anti-Ro, anti-RNP) non-reactive Viral serology (Parvovirus B19, HIV, hepatitis B and C) non-reactive

up to 14 months; therefore, in cases of idiopathic panniculitis, it would be advisable to measure muscle enzyme levels and evaluate the patient periodically. ${ }^{8}$

The incidence of malignancy in adult patients with dermatomyositis ranges from $6 \%$ to $60 \%$ of cases. 9 Only one case of underlying neoplasm (rhabdomyosarcoma in an adult patient) was reported in this group of patients with dermatomyositis associated with panniculitis. ${ }^{3}$

The pathogenesis of this condition is unknown. The presence of simultaneous skin and muscle involvement, and the concomitant appearance of cutaneous alterations in the epidermis and subcutaneous cell tissue suggest that they are related. ${ }^{8}$

Histology shows lobular panniculitis with a lymphoplasmacytic infiltrate, fat necrosis and consequent fibrosis. Calcified areas, ulceration, vasculitis and endothelial edema may also be present. ${ }^{8}$

Pathological studies and clinical observations have suggested that there are different degrees of sub- cutaneous inflammation in dermatomyositis but that only the severe cases are clinically recognized. Nevertheless, some authors believe that the changes observed in the hypodermis are focal, uncommon and not sufficiently characteristic as to constitute a clinical syndrome of panniculitis. ${ }^{8}$

The treatment of choice consists of corticoids, which results in a rapid and complete response ${ }^{3}$ such as that achieved in the present case. Other drugs such as methotrexate or intravenous immunoglobulin are used less frequently in patients who fail to respond to steroids. ${ }^{4,10}$ It is noteworthy that the difference between this condition and lupus panniculitis is that in the former antimalarial drugs have no effect. ${ }^{3}$

The presence of panniculitis in a patient with dermatomyositis is believed to be indicative of good prognosis, since almost all the cases respond well to treatment and malignancy has been detected in only one case. ${ }^{9}$ For some investigators, when dermatomyositis presents together with panniculitis, this represents a distinctive subgroup of the disease. ${ }^{9}$

\section{REFERENCES}

1. Dourmishev LA, Dourmishev AL, Schwartz RA. Dermatomyositis: cutaneous manifestations of its variants. Inter J Dermatol. 2002; 41:625-30.

2. Ortigosa LCM, Reis VMS. Dermatomiosite. An Bras Dermatol. 2008; 83:247-59.

3. Ghali FE, Reed AM, Groben PA, McCauliffe DP. Panniculitis in juvenile dermatomyositis. Pediatr Dermatol. 1999;16:270-2.

4. Chao YY, Yang LJ. Dermatomyositis presenting as panniculitis. Int J Dermatol. 2000;39:141-4

5. Solans R, Cortés J, Selva A, Garcia-Patos V, Jimenez FJ, Pascual C, et al. Panniculitis: a cutaneous manifestation of dermatomyositis. J Am Acad Dermatol. 2002;46:S148-50.

6. Neidenbach PJ, Sahn EE, Helton J. Panniculitis in juvenile dermatomyositis. J Am Acad Dermatol. 1995;33:305-7.

7. Winkelman WJ, Billick RC, Srolovitz H. Dermatomyositis presenting as panniculitis. J Am Acad Dermatol. 1990;23:127-8.

8. Carneiro S, Alvim G, Resende P, Jeunon Sousa MA, Cuzzi T, Ramos-e-Silva M. Dermatomyositis with panniculitis. Skinmed. 2007;6:46-7.

9. Molnár K, Kemény L, Korom I, Dobozy A. Panniculitis in dermatomyositis: report of two cases. Br J Dermatol. 1998;139:161-3.

10. Sabroe RA, Wallington TB, Kennedy CT. Dermatomyositis treated with high-dose intravenous immunoglobulins and associated with panniculitis. Clin Exp Dermatol. 1995;20:164-7.

\footnotetext{
MAILING ADDRESS / ENDEREÇO PARA CORRESPONDÊNCIA:

Dra. Mariana Arias

Belgrano 372 (1876), Bernal, Provincia de Buenos

Aires, Argentina.

Pbone: +541141210856.

E-mail:mariana_arias77@yaboo.com.ar
}

How to cite this article/Como citar este artigo: Arias M, Cunha LGB, Hernández MI, Kien MC, Abeldaño A. Panniculitis in a patient with dermatomyositis. An Bras Dermatol. 2011;86(1):146-8. 